\title{
HARVESTING IN HOLY WATERS: AN OVERVIEW OF FISHERY IN PORTUGAL IN THE LATER MIDDLE AGES AND EARLY MODERN TIMES
}

\author{
Rodrigo da Costa Dominguez \\ UniversidADE Do Minho \\ PoRTUGAL
}

Date of receipt: $29^{\text {th }}$ of May, 2019

Date of acceptance: $17^{\text {th }}$ of February, 2020

\begin{abstract}
Traditional and consolidated Portuguese historiography has seen fishery throughout the Middle Ages, moving towards to Early Modern times, as an economic activity firstly (and mainly) connected to the State's efforts of supplying local markets, as well as to the dynamization of its own economy, within a process of financial and fiscal strengthening of the Portuguese Crown. Bottom line, this development is deeply linked to Portugal's economic history fostering process, which started fifty years ago. In this sense, this essay proposes a historiographic reflection, an overview of what has been done so far. Moreover, we want to observe how it has been historiographically framed by Portuguese historians and international scholars, and highlight most recent tendencies in terms of new approaches and research initiatives.
\end{abstract}

KeYwords

Portugal, Fishery, Middle Ages, Coast, Rivers.

\section{Capitalia Verba}

Portugallia, Piscatio, Medium Aevum, Litus, Flumina. 


\section{Introduction: a historiographical frame on fishery}

The relevance of the sea for peoples' lives in the Later Middle Ages and Early modern period is manifest. It comes from the ancient times, as a mean to occupy other regions and strategic ports along the coastline, as well as to be the roads and paths of merchants to sell their goods and military to conquer other lands. The dimension of a "nourishing sea" is a complementary side of a fundamental dimension, yet seasonal in many cultures, of the human condition: feeding. ${ }^{1}$ In this sense, fishing was one of the fundamental mechanisms that enabled men to explore sea, even more present in the history of Portugal and the Portuguese oceanic expansion. ${ }^{2}$ Notwithstanding the significance of the sea for the Portuguese kingdom, the main intent of this paper is, fundamentally, to bring an updated literature review of such activity having the History of Portuguese Historiography as a guiding line, and provide some remarks of possible open paths for future researchers to explore it.

Despite the fact that many and different states of the art regarding fishery have been done, it is possible to observe that two main perspectives have dominated the historiography of fishing in Portugal for the period analyzed. On one hand, a fundamental and traditional economic activity, based on ancient roman and Mozarabic heritage, ${ }^{3}$ fundamentally committed to the kingdom's efforts of providing food for their subjects and a commodity for local and regional markets' trade. On the other hand, by doing that, kings were seeking the improvement of their own economy, within a context of the Crown's monetary and fiscal establishment. Bottom line, both visions are deeply connected to a positive background scenario: the 'rebirth' of Portuguese Economic History over the last 50 years. The king's concerns with the balance of trade with other European kingdoms, as well as the State's financial needs that would help enable a transition process towards to a fiscal consolidation, according to some scholars, have dictated a central line of action for fishing in the Middle Ages and Early Modern times in Portugal, particularly concerning the Crown's policy of political and economic strengthening from 1250s onwards. ${ }^{4}$

However, following the historiographic thread backwards, late nineteenthcentury and early twentieth-century Portuguese scholars, such as Alexandre Herculano, Oliveira Martins and João Lúcio de Azevedo wrote about Portugal's medieval economic roots, much embedded of a modernity idea, mainly sustained

1. Bresc, Henri. "Mar", Dicionário Temático do Ocidente Medieval, Jacques Le Goff, Jean-Claude Schmitt, coords. São Paulo: Editora da Universidade do Sagrado Coração, 2006: II, 95-98.

2. Castro, Armando. A evolução económica de Portugal dos séculos XII a XV. Lisbon: Portugália, 1966: IV, 105-110.

3. Castro, Armando. A evolução económica...: IV, 92-132; Marques, António Henrique de Oliveira. "O Portugal Islâmico. A valorização económica", Nova História de Portugal. Vol. II: das invasões germânicas à Reconquista, António Henrique de Oliveira Marques, coord. Lisbon: Presença, 1993: 162. See also Alarcão, Jorge de. Portugal Romano. Lisbon: Verbo, 1973; Alarcão, Jorge de, coord. Nova História de Portugal. Vol. I: das origens à Romanização. Lisbon: Presença, 1990.

4. Mattoso, José. Identificação de um País. Ensaio sobre as origens de Portugal (1096-1325). Vol. II. Composição. Lisbon: Editorial Estampa, 1995: 37-38. 
by an internal political conflict between republicans and monarchists and their different visions of nation, nationalism and society. ${ }^{5}$ In the midst of a conjuncture of exalted moods, of extreme visions, of a Portugal marked by the early years of a young Republican regime, the campaign in the Great War and in search of compiling and amalgamating all its elements in the formation of a "Portuguese culture", ${ }^{6}$ ruling classes would try to forge the notion of heritage. At the same time, the myth of a New Nation ${ }^{7}$ was dangerously and problematically cultivated. The natural tendency for an institutional perspective, mostly derived from the History of Law, led some Portuguese historians - or at least economic historians - to ignore or engage in a shallow and scarce way most of Portugal's economic activities, including fishery, ${ }^{8}$ following previous traditional viewpoints or studies from experts with empiric knowledge, mostly from naval and military background. ${ }^{9}$

Back in the 1950s, the first steps of an awakening were taken by A. H. de Oliveira Marques and his work in economic topics, such as trade with Northern Europe, ${ }^{10}$ highlighting the important role played by the Portuguese commodities, mainly fruit, wine, cork, cod and salt, this last one fundamental for fishery industry. The latter would also be the main topic for the work of another economic history pioneer, Virgínia Rau. Her work about the salt industry at Setúbal ${ }^{11}$ served for many generations as a fundamental reference for Portugal's financial and fiscal studies, ${ }^{12}$ which also related with both internal and international commercial activities, as well as local production rhythms, provided many hints to those who wanted to study about fishing and its economic impacts within Portuguese society.

Entering the 1960s, Portugal witnessed a renaissance of economic and social studies in general, but with deeper effects related to the Late Middle Ages and Early Modern times, mostly due to a new vision. At that time, a new agenda arose,

5. About those differences, see Magalhães, Joaquim Romero. Vem aí a República, c. 1906-1910. Coimbra: Almedina, 2009: 321-345.

6. Ramos, Rui. “A invenção de Portugal”, História de Portugal. Vol. 12. A Segunda Fundação, José Mattoso, dir. Algueirão-Mem Martins: Círculo de Leitores, 2008: 257.

7. Ramos, Rui. “A traição dos intelectuais”, História de Portugal. Vol. 12. A Segunda Fundação, José Mattoso, dir. Algueirão-Mem Martins: Círculo de Leitores, 2008: 221-222; Rosas, Fernando. "O Salazarismo e o homem novo: ensaio sobre o Estado Novo e a questão do totalitarismo". Análise Social, $35 / 157$ (2001): 1034-1035.

8. For instance, the idea of an agrarian monarchy defended by João Lúcio de Azevedo was strongly challenged in the 1950s and 60s. His point of view is reduced to a couple mentions, about the Portuguese vocation and tradition regarding fishery and navigation, as well as a possible linkage between the people and a "crusadistic heritage" in terms of exploring new paths, sailing and shipbuilding techniques. Azevedo, João Lúcio de. Épocas de Portugal Económico: esboços de História. Lisbon: Livraria Clássica Editora, 1973: 17, 27-28.

9. See d'Eça, Vicente Almeida. A Pesca. Lisbon: Imprensa Nacional, 1929.

10. See Marques, António Henrique de Oliveira. Hansa e Portugal na Idade Média. Lisbon: Universidade de Lisboa (PhD Dissertation): 1959.

11. See Rau, Virgínia. A exploração e o comércio do sal de Setúbal: estudo de história económica. Lisbon: Bertrand, 1951; Rau, Virgínia. Estudos sobre a história do sal português. Lisbon: Presença, 1984.

12. See Rau, Virgínia. A Casa dos Contos. Coimbra: Instituto de Estudos Históricos Dr. António de Vasconcelos, 1951 . 
proposed by a new generation of historians, compromised with the necessity of different approaches of Medieval sources, mostly under the aegis of the consolidation of Economic History, internationally speaking, with particular strength during the late 1960s and early 1970s. That generation, led by the same Oliveira Marques, plus Vitorino Magalhães Godinho, and Jaime Cortesão suggested and followed a different path, away from previous traditional perspectives, much embedded of a modern idea, underpinned by a contraposition against scientificism and positivism, mainly brought by early twentieth-century Portuguese scholars previously mentioned.

Those, who devoted their academic lives to a broader range of economic topics, signaled back in the mid-1960s the urgency of address medieval problems of the Portuguese society, including

A história económica geral começa por abordar a produção — produção agropecuária, antes de tudo, atendendo às condições e aos meios do solo arável, das pastagens, da mão-de-obra, das áreas cultivadas, analisando depois produtos e quantitativos, tipos de gado, etc.; produção aquática, com suas formas de pesca fluvial e marítima e de salicultura. ${ }^{13}$

The urge to develop economic history within the medieval and early modern scopes, to bring new data, combined with the use of royal chronicles and chancery records, ${ }^{14}$ provided the first historiographic results, serving as a starting point for the next generation of economic historians that would came up in the subsequent decades. Nevertheless, following the development of Portuguese economic studies, fishery came up as one of the main topics that testified a massive growth, carried by methodology improvements and new quantitative and qualitative approaches on sources previously explored.

Ao lado da produção agrícola encontramos aquilo a que poderíamos chamar a produção aquicola, especialmente traduzida no peixe e no sal. [...] seria a riqueza piscatória da plataforma continental portuguesa superior ou inferior à de nossos dias? Por que motivo se interessaram tanto os pescadores portugueses em demandar águas territoriais estrangeiras (Marrocos e Inglaterra, por exemplo) a ponto de conseguirem até facilidades anormais?

Quais os peixes mais vulgares no rio e no mar? A documentação não se mostra avara na definição das principais espécies e sua distribuição por áreas geográficas. Permitiu também a delimitação das zonas salineiras. Mais dificilmente nos revelará números tradutores do seu papel na economia de então.

As técnicas de extracção de sal foram já estudadas; falta-nos fazer outro tanto para as técnicas piscatórias. A pesca da baleia merecerá especial relevo. Interessar-nos-ia também saber até

13. "General economic history approaching the production —agricultural production, first of all, taking into account the conditions and resources of arable land, pasture, manpower, cultivated areas, then analyzing products and quantities, livestock types, etc.; aquatic production, with its forms of river and sea fishing and salt production." Marques, António Henrique de Oliveira. Guia do Estudante de História Medieval Portuguesa. Lisbon: Cosmos, 1964: 13.

14. Santos, João Marinho dos. "O Mar e a Independência Nacional. Relendo Jaime Cortesão". Revista de História da Sociedade e da Cultura, 7 (2007): 264-265. See also Castro, Armando. A evolução económica de Portugal dos séculos XII a XV. Lisbon: Portugália, 1964-1970, 9 vols. (see volumes I and IV in particular). 
que ponto os portugueses dos séculos XII e XIV aproveitaram integralmente o peixe e os cetáceos, extraindo óleos, pele e outros derivados.

Por último, haveria que estudar as formas de exploração; quem possuía os barcos para a pesca ou as salinas - individuos, parcerias, sociedades, a Coroa, o rei? Quem financiava os empreendimentos? Que tributação onerava a pesca e o sal? Qual o rendimento respectivo? E assim por diante. ${ }^{15}$

One of the first attempts was made by Vitorino Magalhães Godinho. His work, essentially devoted to economic perspectives and topics, such as prices, currencies and markets, had also a relevant contribute to the Portuguese oceanic expansion. ${ }^{16}$ He brought to the historians' horizon the connection between the discoveries and the fishermen's experience, in the sense of the importância do "alargamento das áreas de pescaria" no achamento de terras novas, no tecer das rotas mercantis, na formação de uma economia-mundo capitalista e na própria configuração de Portugal como um Reino e Estado-nação marítimo. ${ }^{17}$ Regarding local approaches, some contributions were made to insert Porto's contribution to the age of discoveries, ${ }^{18}$ which brought some aspects of fishery.

At this point (1960s and 1970s), Portuguese historiography was shaken by the last harsh years of Salazar's regime, illustrated by some persecution of personal and ideological character. Many economic historians —including Godinho himself-

15. "Next to agricultural production we find something that we could call the aquacultural production, especially translated to fish and salt. [...] was the fishing wealth of the Portuguese continental shelf superior or inferior to that of our days? For which reason Portuguese fishermen were so interested in explore international waters (Britain and Morocco, for example) to the point of getting unusual privileges? / Which were the most common species in rivers and sea? The sources are not stingy in the definition of the main species and its distribution by geographic areas. It also allowed us the delimitation of salt areas. More hardly will reveal numbers to translate its role within the local economy at that time. / The techniques of salt extraction were already studied; it is missing to do more for fishery techniques. Whale fishery would also deserve more attention. In this sense, we would be interested to know until which point the twelfth and thirteenth-century Portuguese people fully harnessed fish and cetaceans, extracting oils, skin and other derivatives. / Last, it would have to be studied the exploration forms; who owned the fishery ships or salines -individuals, partnerships, societies, the Crown, the king? Who financed the enterprises? Which taxes were levied on those activities? Which were the revenues? And so on." Marques, António Henrique de Oliveira. “Ideário para uma História Económica de Portugal na Idade Média", Ensaios de História Medieval Portuguesa. Lisbon: Vega, 1980: 30-31, originally published as Marques, António Henrique de Oliveira. "Ideário para uma História Económica de Portugal na Idade Média". Revista de Economia, 14/3 (1962): 181-197.

16. See Godinho, Vitorino Magalhães. Os Descobrimentos e a Economia Mundial. Lisbon: Arcádia, 1965,2 vols. See also Cortesão, Jaime. Os factores democráticos na formação de Portugal. Lisbon: Livros Horizonte, 1974; Pedrosa, Fernando Gomes. Os homens dos descobrimentos e da expansão marítima: pescadores, marinheiros e corsários. Cascais: Câmara Municipal de Cascais, 2000.

17. "importance of 'fishing areas enlargement process' in the findings of new lands, in the merchants' networks building process, in the formation of a worldwide capitalist economy and within Portugal's configuration as a kingdom and maritime state-nation." Garrido, Álvaro. "As pescarias e o ordenamento do mar entre o Mito da 'Nação Marítima' e as Realidades do 'Estado Costeiro'”, Economia, Instituições e Império: estudos em homenagem a Joaquim Romero Magalhães, Álvaro Garrido, Leonor Freire Costa and Luís Miguel Duarte, eds. Coimbra: Almedina, 2012: 595.

18. See Cruz, António. “O Porto na génese dos Descobrimentos”. Studium Generale, 7 (1960): 1-103. 
were defamed and reported by his own colleagues as subversives, going abroad to find some peace and better conditions to develop research and teach. ${ }^{19}$ On the other hand, Historian's fierce criticism to Salazar's dictatorship and to the colonial war in Africa, establishing a milestone of resistance. However, they would have to wait for the Carnation Revolution in 1974 to find peace and openness. The new winds of liberty would also bring freshness and new perspectives not only for Economic History in general, but also for the history of fishery.

\section{Fishery in Late Middle Ages and Early Modern Times: possible approaches and developments}

Rather than globally or nationally, fishery in Portugal had to be seen locally first, piece by piece, from regional studies, creating and assembling the whole puzzle slowly, in order to build the big picture. In this sense, and now enjoying other political conditions, its history started to be developed by the hands of Joaquim Romero Magalhães in his studies approaching mostly the Algarve, his homeland, for the sixteenth ${ }^{20}$ and seventeenth ${ }^{21}$ centuries. As a disciple of Vitorino Magalhães Godinho, his work highlighted the important economic role played by that region during the later middle ages and early modern times. Furthermore, he emphasized the importance of fishery, particularly tuna, ${ }^{22}$ not only for Southern local economy, but also for the whole kingdom, both in terms of GDP and fiscal revenues, establishing a fundamental benchmark for Portuguese Medieval and Early Modern Economic, Fiscal and Fishery history.

Historically, Portugal built its fishing traditions in local clusters that had to do with the junction of mainland's main rivers with the sea. ${ }^{23}$ Recently, new approaches on Portuguese Medieval fishing had seen the activity through the geographical aspect, observing its dynamics from the standpoint of each geographic area but aiming for an assembling of a national scenario, based on a very important set of

19. Magalhães, Joaquim Romero. "Breve Panorama da História Económica em Portugal, 1860-2004", No Portugal Moderno: Espaços, Tratos e Dinheiros: Miúnças 3, Joaquim Romero Magalhães, ed. Coimbra: Imprensa da Universidade de Coimbra, 2012: 341.

20. See Magalhães, Joaquim Romero. Para o estudo do Algarve económico durante o século XVI. Lisbon: Cosmos, 1970.

21. See Magalhães, Joaquim Romero. O Algarve Económico, c. 1600-1773. Lisbon: Editorial Estampa, 1988. 22. Magalhães, Joaquim Romero. O Algarve na Época Moderna. Coimbra: Imprensa da Universidade de Coimbra, 2012: 55-68 (chapter “Panorama Social e Económico do Algarve na Época de D. Jerónimo Osório"). About tuna fishing, see also Leite, Alberto. Contribuição para a divulgação das principais artes de pesca ao atum. Lisbon: Instituto Nacional de Investigação das Pescas, 1985; Costa, Fausto. A pesca do atum nas armações da costa algarvia. Lisbon: Bizâncio, 2000. Regarding the importance of tuna fishing for Portugal's State finances, see Dominguez, Rodrigo da Costa. O Financiamento da Coroa Portuguesa nos finais da Idade Média: entre o "Africano" e o "Venturoso". Porto: Universidade do Porto (PhD Dissertation), 2013: $115-116$.

23. See Branco, Fernando Castelo. "Do tráfego fluvial e da sua importância na economia portuguesa". Boletim da Sociedade de Geografia de Lisbon, 76/1 (1958): 39-66. 
sources little explored until then. ${ }^{24}$ This method has been used before, but only seen each region separately, as for the Algarve (South) for which we have some studies already mentioned above. About the center-south coast, some works have privileged important traditional fishing nuggets, such as the Sado River mouth, composed by a group of cities that fundamentally lived from the salt and fishery industry, such as Sesimbra, Setúbal and Alcácer do Sal. ${ }^{25}$ In this particular region, most of fishing activities were attached to the Military Order of Santiago since the thirteenth century, granted by King Alfonse III (1248-1279), given its economic relevance in terms of revenues, key aspect for the Reconquista in Portuguese lands. ${ }^{26}$ Fundamental aspects of fishing culture, such as the material used to manufacture fishing tools, ${ }^{27}$ were also privileged by some studies. Nevertheless, fishery during the last two reigns of the Burgundy dynasty -Peter I (1357-1367) and Ferdinand I (1367-1383) - had also been subject of older studies ${ }^{28}$ that served as a base for comparative views between local economic activities and main sources of revenues.

In the 1970s and 1980s, important references for fishery industry would arose, following the trend of medieval sources' editing and re-editions of older works, still trailing the analysis of specific regional spaces. ${ }^{29}$ In this sense, more local case studies were emerging from central Portugal, supported and boosted by social history methods, trying to reconstruct different aspects of Portuguese Medieval society. ${ }^{30}$ In this sense, more work related to fishermen's role for inter-regional communicating, both among coastal cities and with hinterland's villages integration

24. História Florestal, Aquícola e Cinegética. Colectânea de Documentos existentes no Arquivo Nacional da Torre do Tombo. Chancelarias Reais, dir. Carlos Manuel L. Baeta Neves. Lisbon: Ministério da Agricultura e Pescas, 1980-1988, 5 vols. For this broader scenario, we followed the work of Gomes, Sandra Rute Fonseca. Territórios Medievais do pescado do Reino de Portugal. Coimbra: Universidade de Coimbra (M.A. Dissertation), 2011.

25. See Cruz, Maria Alfreda. Pesca e pescadores em Sesimbra. Lisbon: Instituto de Alta Cultura-Centro de Estudos Geográficos da Universidade de Lisboa, 1966; Marques, António Reis. As artes de pesca de Sesimbra. Sesimbra: Câmara Municipal de Sesimbra, 2000; Cunha, Rosalina B. da Silva. "Subsídios para a conservação do peixe em Portugal do século XII ao XVI". Boletim da Biblioteca da Universidade de Coimbra, 29 (1972): 5-72.

26. Gomes, Sandra Rute Fonseca. Territórios Medievais do pescado...: 12-13. About the Order of Santiago, see Pimenta, Maria Cristina Gomes, ed. “As ordens de Avis e de Santiago na Baixa Idade Média: O Governo de D. Jorge". Militarium Ordinum Analecta, 5 (2001): 31-244.

27. The use of cork to manufacture floats of fishing nets is described in Pessanha, Sebastião. "Alguns flutuadores dos aparelhos de pesca usados em Portugal". Revista de Etnografia: Museu de Etnografia e História, 20 (1968): 235-252.

28. See Cunha, Maria do Carmo Rodrigues da Silva. A caça e a pesca fluvial nos reinados de D. Pedro I e D. Fernando. Coimbra: Universidade de Coimba (M.A. Dissertation), 1959.

29. See Sampaio, Alberto. Estudos históricos e económicos. Vol. II: as póvoas marítimas. Lisbon: Vega, 1979; Livro das Posturas Antigas de Lisbon, ed. Maria Teresa Campos Rodrigues. Lisbon: Câmara Municipal de Lisbon, 1974; Posturas do Concelho de Lisbon (século XIV), ed. José Pedro Machado. Lisbon: Sociedade de Língua Portuguesa, 1974.

30. See Beirante, Maria Ângela. Santarém Medieval. Lisbon: Faculdade de Ciências Sociais e HumanasUniversidade Nova de Lisboa, 1980; Beirante, Maria Ângela. Santarém Quinhentista. Lisbon: without publisher, 1981. 
to main towns, ${ }^{31}$ as well as to consumption habits and different species present in the Portuguese coastline also started to show up, referencing sardines as the main one, but also the halibut, conger, croaker, horse-mackerel and the mullet. ${ }^{32}$ Following the social history trend - or even rural history-, fishing techniques and its instruments ${ }^{33}$ were also object to develop more erudite descriptions of Portugal fishery and local economic development in different regions. ${ }^{34}$ Moreover, fishery was also studied as part of the economic deals involving foreign investors and their investment strategies regarding tax-farming and other monopolies offered by the Crown, following the tendency of public-private partnerships ${ }^{35}$ to foster financial input provided by new conquered regions during the Oceanic expansion era.

Moving from the 1980s towards to the 1990s, relevant contributions in terms of different variants of river fishing ${ }^{36}$ were incorporated to the set of studies that still had focus on Portuguese society, its distribution along the coast ${ }^{37}$ and its way of life. ${ }^{38}$ By the same time, more volumes of the History of Portugal, directed by José Mattoso and wrote/coordinated by Joaquim Romero Magalhães, as well as the New

31. See Moreno, Humberto Baquero. “A acção dos almocreves no desenvolvimento das comunicações inter-regionais portuguesas nos fins da Idade Média", Papel das áreas regionais na formação histórica de Portugal, Lisbon, 1975. Actas do colóquio. Lisbon: Academia Portuguesa de História, 1975: 185-239.

32. Santos, Maria José Azevedo. “O Peixe e a Fruta na Alimentação da Corte de D. Afonso V: breves notas". Brigantia, $3 / 3$ (1983): 309-310; Marques, António Henrique de Oliveira. “A propriedade fundiária e a produção", Nova História de Portugal. Vol. IV: Portugal na crise dos séculos XIV e XV, António Henrique de Oliveira Marques, coord. Lisbon: Presença, 1987: 110.

33. Espinosa, Fernanda. Escritos Históricos. Porto: Porto Editora, 1972: 149-164 (chapter "Notas sobre a Actividade Piscatória na Economia Marítima da $1^{\text {a }}$ Dinastia"); Coelho, Maria Helena da Cruz. O Baixo Mondego nos finais da Idade Média: estudo de História Rural. Coimbra: Universidade de Coimbra (PhD Dissertation), 1983, 2 vols. About rural history and an important balance of what had been done in Portugal until the late 1990s, see Coelho, Maria Helena da Cruz. "Balanço sobre a história rural produzida em Portugal nas útimas décadas". História Revista, 2/1 (1997): 7-32.

34. See Filgueiras, Octávio Lixa. "Cooperativas de pesca: primeiros ensaios na Póvoa de Varzim". Boletim Cultural da Póvoa de Varzim, 19/1 (1980): 5-34; Filgueiras, Octávio Lixa. "Barcos de pesca de Portugal". Revista da Universidade de Coimbra, 28 (1980): 344-388; Filgueiras, Octávio Lixa. "Fishing crafts in Portugal", The Fishing Culture of the World: studies in Etnology, Cultural Ecology and Folklore, Béla Gunda, ed. Budapest: Akadémiai Kiado, 1983: II, 143-180.

35. Rau, Virgínia. Estudos de História Medieval. Lisbon: Presença, 1986: 150-151 (chapter “Aspectos do 'trato' da 'adiça' e da 'pescaria' do 'coral' nos finais do século XV").

36. Coelho, Maria Helena da Cruz. "A pesca fluvial na economia e sociedade medieval portuguesa", Actas do Seminário "Pescas e Navegações na História de Portugal (séculos XII a XVIII)". Lagos: Comissão Municipal dos Descobrimentos, 1992: 81-102.

37. Peixoto, Luís Correia. Apontamentos para a história da pesca da sardinha e da construção naval em Peniche. Peniche: Câmara Municipal de Peniche, 1991; Barbosa, Pedro Gomes. Documentos, lugares e homens: estudos de história medievai. Lisbon: Cosmos, 1991: 105-131 (chapter “Alguns grupos marginais nos documentos de Santa Maria de Alcobaça (sécs. XII e XIII)"); Barbosa, Pedro Gomes. Povoamento e estrutura agrícola na Estremadura Central: século XII a 1325. Lisbon: Instituto Nacional de Investigação Científica, 1992.

38. Monteiro, Rafael. "O vestuário dos homens do mar", Actas do Colóquio "Santos Graça" de etnografia marítima, João Marques, coord. Póvoa de Varzim: Câmara Municipal da Póvoa de Varzim, 1986: IV, 9395; Ventura, Margarida Garcez. “Em torno do cumprimento do preceito dominical pelos pescadores (sécs. XV-XVIII)", Carlos Alberto Ferreira de Almeida, in memoriam, Mário Jorge Barroca, coord. Porto: Faculdade de Letras da Universidade do Porto, 1999: II, 435-448. 
History of Portugal, directed by Oliveira Marques, were issued, ${ }^{39}$ covering little bits of fishery topics by an Annales standpoint, i.e., big collections trying to cover as many themes as possible, bringing new questions and new research dossiers for further studies, without neglecting scientific rigor, of course, on one hand, but not deep, descriptive and developed enough on the other hand, but with a selection of primary sources to illustrate each case, regarding every subject. By that time, most of the publications and research done were bringing up the dominant role played by cod within fishery industry towards the Early Modern times. ${ }^{40}$ This actually will be a key period regarding a transition phase for this species. Despite the variety along the Portuguese coast mentioned by previous works, cod will become one of the main commodities, both imported and exported, being responsible for a bulk of State's revenues.

This precise development regarding the history of cod fishery industry, which had some developments from the mid-1980s onwards, ${ }^{41}$ will actually boost most of historiographic production, which will have its core during the late 1990s and 2000s, experiencing some sort of a "rebirth" since the first studies of the 1940s. ${ }^{42}$ Furthermore, most of its studies were centered in two institutions/universities, following the thread of doing local case studies to pursue, lately, the building of a national scenario. In Porto, the work done by a new generation of historians centralized the efforts to reveal more about fishery in Northern Portugal, carrying on some research with a blend of global, economic and social history approaches,

39. Magalhães, Joaquim Romero. “A indústria”, História de Portugal. Vol. III: no Alvorecer da Modernidade, Joaqium Romero Magalhães, coord. Lisbon: Estampa, 1993: 283-314; Serrão, José Vicente. “O quadro económico: configurações estruturais e tendências de evolução", História de Portugal. Vol. 4: o Antigo Regime, António Manuel Hespanha, coord. Lisbon: Estampa, 1993: 71-117; Marreiros, Maria Rosa Ferreira. “Os proventos da Terra e do Mar", Nova História de Portugal: vol. III. Portugal em definição de fronteiras, Maria Helena da Cruz Coelho, Armando Luís de Carvalho Homem, coords. Lisbon: Presença, 1996: 400-475; Braga, Isabel M. R. Mendes Drumond. "A Circulação e a Distribuição dos Produtos", Nova História de Portugal: vol. IV. Portugal na crise dos séculos XIV e XV, António Henrique de Oliveira Marques, coord. Lisbon: Presença, 1996: 195-247.

40. See Abreu-Ferreira, Darlene. "Terra Nova through the Iberian Looking Glass: The PortugueseNewfoundland Cod Fishery in the Sixteenth Century". The Canadian Historical Review, 79/1 (1998): 100-117; Abreu-Ferreira, Darlene. "The Portuguese in Newfoundland: Documentary Evidence Examined". Portuguese Studies Review, 4/2 (1995-1996): 11-33; Abreu-Ferreira, Darlene. "Portugal's Cod Fishery in the 16th Century: Myths and Misconceptions", How Deep is the Ocean? Essays on the History, Sociology, Archaeology, and Ecology of the Canadian East Coast Fishery, James E. Candow, Carol Corbin, eds. Halifax: The Louisbourg Institute, 1997: 31-44.

41. See Moutinho, Mário. História da pesca do bacalhau: por uma antropologia do "fiel amigo". Lisbon: Estampa, 1985; Marques, Francisco. Faina maior: a pesca do bacalhau nos mares da Terra Nova. Lisbon: Quetzal, 1996; Pata, Manuel Luís, coord. A Figueira da Foz e a pesca do bacalhau, achegas para a história. Vol. 1 (das origens a 1933). Figuera da Foz: Centro de Estudos do Mar, 1997; Silva, António Marques da. $A$ memória dos bacalhoeiros: uma contribuição para a sua história. Lisbon: Presença, 1999.

42. Cajeira, José Pereira. Da evolução histórica e económica da pesca do bacalhau. Coimbra: without publisher, 1941; Simões, Jorge. Os grandes trabalhadores do mar: reportagens na Terra Nova e na Groenlândia. Lisbon: without publisher, 1942; Cruz, Frederico. Fainas do mar. Lisbon: Livraria Civilização, 1946. 
such as Amélia Polónia ${ }^{43}$ and Amândio Barros. ${ }^{44}$ Furthermore, the work done by Inês Amorim became a reference for the history of fishing in Portugal in the later Middle Ages and Early Modern times. First place, it was circumscribed to the region of Aveiro, one of the main ports of Portugal's coastline, and local dynamics and practices during the 1600s and 1700s, mostly related to the techniques for salting and fish preservation, especially for sardines. ${ }^{45}$ Nevertheless, her work would also contemplate an important contribution for cod fishery history, as well as fishing in general, mostly seen through the fiscal perspective. ${ }^{46}$

In Coimbra, at the Faculty of Economics, much labor was done regarding fishing history, following the research stimulated and galvanized by Álvaro Garrido. With an initial framework for cod fishing and consumption in contemporary Portugal, ${ }^{47}$ plenty of effort was developed to broader the chronology, in order to provide a fertile environment for further studies to deepen knowledge about the "faithful friend" — as cod is popularly known in Portugal- for previous periods but also for a comparative perspective in time. ${ }^{48}$ Furthermore, other studies followed this

43. See Polónia, Amélia. Vila do Conde: um porto nortenho na expansão ultramarina. Porto: Universidade do Porto (PhD Dissertation), 1999, 2 vols; Amorim, Inês; Polónia, Amélia. “Gestão de espaços de pesca: poder, administração e conflitos na época moderna: um estudo de caso: as pesqueiras do Rio Ave". Oceanos, 47/48 (2001): 30-46.

44. See Barros, Amândio Jorge Morais. "Barcos e Gentes do Mar do Porto (séculos XIV-XV)". Revista da Faculdade de Letras. História, 14 (1997): 167-230; Barros, Amândio Jorge Morais. Porto: a construção de um espaço marítimo nos alvores dos tempos modernos. Porto: Universidade do Porto (PhD Dissertation), 2004.

45. See Amorim, Inês. “Da pesca à salga da sardinha: recursos, tecnologia da pesca e tecnologia da conservação, na costa de Aveiro ( $2^{a}$ metade do séc. XVIII a inícios de XIX)", A Indústria Portuense em perspectiva histórica. Actas do Colóquio. Lisbon: Faculdade de Letras da Universidade do Porto-Centro Leonardo Coimbra, 1998: 25-43; Amorim, Inês. "Recursos marítimos e tecnologia no séc. XVIII: pesca, sal e moliço no litoral e na Ria de Aveiro", O litoral em perspectiva histórica (séc. XVI-XVIII): actas, Inês Amorim, Amélia Polónia, Helena Osswald, coords. Porto: Instituto de História Moderna-Centro Leonardo Coimbra, 2002: 185-204.

46. Amorim, Inês. "O Porto de Aveiro e as pescarias na época moderna", A pesca do bacalhau. História e Memória, Álvaro Garrido, coord. Lisbon: Editorial Notícias, 2001: 51-84; Amorim, Inês. “A organização dos Serviços de Pescas e da Aquacultura e as iniciativas de instrução científico-técnica: século XII a inícios do séc. XX". Mare liberum: revista de história dos mares, 21 -22 (2001): 123-164; Amorim, Inês. "A decadência das pescarias portuguesas e o constrangimento fiscal: entre a Ilustração e o Liberalismo", Estudos em Homenagem a Luís António de Oliveira Ramos, Francisco Ribeiro da Silva, coord. Porto: Faculdade de Letras da Universidade do Porto, 2004: 153-164; Amorim, Inês. "Portuguese Fisheries, c. 1100-1830", A History of the North Atlantic Fisheries. Vol. 1: From Early Times to the Mid-Nineteenth century", David Starkey, John Thór, Hingo Heidbrink, eds. Bremen: German Maritime Museum of Bremerhaven, 2009: 279-298; Amorim, Inês. “The Evolution of Portuguese Fisheries in the Medieval and Early Modern Period: a Fiscal Debate, Beyond the Catch. Fisheries of the North Atlantic, the North Sea and the Baltic, 900-1850, Louis Sicking, Darlene Abreu-Ferreira, eds. Leiden-Boston: Brill, 2010: 245-279; Amorim, Inês; Leite, Capitão Bento de Assunção. Glossário Ilustrado de Pesca. Póvoa do Varzim: Câmara Municipal da Póvoa do Varzim, 2009. 47. See Garrido, Álvaro. Abastecimentos e poder no salazarismo:o "bacalhau corporativo" (1934-1967). Coimbra: Universidade de Coimbra (PhD Dissertation), 2003, 2 vols; Garrido, Álvaro. O Estado Novo e a campanha do Bacalhau. Lisbon: Círculo de Leitores, 2004; Garrido, Álvaro. Economia e política das pescas portuguesas: ciência, direito e diplomacia nas pescarias do bacalhau (1945-1974). Lisbon: Imprensa de Ciências Sociais, 2006. 48. See Amorim, Inês; Garrido, Álvaro, coords. Behaviour in social dilemas: toward sustainable fishery systems: a historical perspective. $9^{\text {th }}$ Conference of the North Atlantic Fisheries History Association (NAFHA), 5-8 december 2005. Porto: Universidade do Porto, 2005. 
path, opened by António de Oliveira ${ }^{49}$ in the early 1970s and Maria Helena da Cruz Coelho in the early 1980s. Her research on the Mondego River region contemplated some features of local river fishing activities within a combination of social and rural history approaches and a broader view of its economic dynamics, mostly connected with the lives of local monasteries and religious orders, with their food habits. ${ }^{50}$

Recently, more studies have been devoted to the analysis of fishery, yet in terms of regional approaches and articulations, but now more has been done in terms of an attempt to assemble a not only a national view regarding this topic, but also regional, long-run and global perspectives. ${ }^{51}$ Over the last decade, new MA. and PhD thesis were freshly written, many of them bringing good and complementary states of art and bibliography about the topic, each of them in its own field of expertise, either in history or other complementary areas. ${ }^{52}$ Furthermore, other efforts in comparative perspective regarding Iberia and Europe, ${ }^{53}$ within a global history angle, had contributed to the historiography of medieval and early modern fishing in Portugal, with a specific focus on the salt industry, ${ }^{54}$ one of the main points of contact. Last, but not least, other paths in terms of ethnography and history have been developed, in the sense of showing new possibilities and approaches ${ }^{55}$ of fishery in terms of

49. See Oliveira, António de. A vida económica e social de Coimbra de 1537 a 1640. Coimbra: Universidade de Coimbra (PhD Dissertation), 1972, 2 vols.

50. Coelho, Maria Helena da Cruz. "Receitas e despesas do mosteiro de Santa Cruz de Coimbra em 1534-1535", Homens, Espaços e Poderes séculos XI-XVI. Vol. II: Domínio Senhorial. Lisbon: Livros Horizonte, 1990: 96; Coelho, Maria Helena da Cruz. O Baixo Mondego nos finais da Idade Média: estudo de História Rural. Coimbra: Universidade de Coimbra (PhD Dissertation), 1983: I, 43-53.

51. See Pope, Peter E. Fish into Wine: The Newfoundland Plantation in the Seventeenth Century. VirginiaChapel Hill: Omohundro Institute of Early American History and Culture-University of North Carolina Press, 2012; Garrido, Álvaro. As Pescas em Portugal. Lisbon: Fundação Francisco Manuel dos Santos, 2018. 52. See, for exemple, Brito, Cristina. Os mamíferos marinhos nas viagens marítimas pelo Atlântico entre os séculos XV e XVIII: a evolução da ciência e do conhecimento. Lisbon: Universidade de Lisboa (PhD Dissertation), 2010; Gomes, Sandra Rute Fonseca. Territórios Medievais do Pescado do Reino de Portugal. Coimbra: Universidade de Coimbra (MA Dissertation), 201 1; Pereira, Olegário Nelson Azevedo. Em torno da pesca, na costa Norte de Portugal, nos séculos finais da Idade Média (1292-1493). Porto: Universidade do Porto (MA Dissertation), 2012: 11 -33; Azevedo, Catarina Sofia da Silva. A Memória e o Património Marítimo da Costa Norte de Portugal. Braga: Universidade do Minho (MA Dissertation), 2013; Silva, Diana Isabel Rocha. Comunidade Piscatória de Vila Chã (Vila do Conde): pescadeiras, pescadores, embarcações e artes de pesca. Porto: Universidade do Porto (MA Dissertation), 2014.

53. See Barros, Amândio Jorge Morais. “Merchants, ports and hinterlands. The building of sea-port structures in the Early Modern Porto". Revista da Faculdade de Letras. História, 9/1 (2008): 89-112; López Losa, Ernesto; Amorim, Inês. "The fisheries of Iberian Peninsula in modern times", A history of the North Atlantic fisheries. Vol. 2: from the 1850s to the early twenty-first century, David J. Starkey, Ingo Heidbrink, eds. Bremen: German Maritime Museum of Bremerhaven, 2012: 253-276; Starkey, David J. "Fish and Fisheries in the Atlantic World", The Atlantic World, D'Maris Coffman, Adrian Leonard, William O'Reilly, eds. London-New York: Routledge, 2015: 55-75.

54. See Barros, Amândio Jorge Morais. “A contabilidade de um produto estratégico: o livro da imposição do sal, século XVI", I Seminário Internacional sobre o sal português, Inês Amorin, coord. Porto: Universidade do Porto, 2005: 75-89. See also Amorim, Inês, coord. A articulação do sal português aos circuitos mundiais: antigos e novos consumos. Porto: Universidade do Porto, 2008, especially the articles of Amândio Barros, Sara Pinto, Valdo d'Arienzo and Cátia Antunes.

55. See Nunes, Francisco Oneto, coord. Culturas Marítimas em Portugal. Lisbon: Âncora editora, 2008. 
maritime populations, social constructions and economic dynamics in which those groups are inserted.

Following this thread, it is very interesting - and worrying - to note that not a single collective research and development project has been submitted in Portugal with a specific focus on fishery in the Later Middle Ages over the last two decades. ${ }^{56}$ Some interdisciplinary research has been conducted about Early Modern times on fishing and parallel topics, being the main subject/method of such initiatives for this particular period —as the salt—, ${ }^{57}$ as well as other periods within the Portuguese History that observed the logics and logistics of labor unions and their private archives. ${ }^{58}$ Nevertheless, not even with the financial boost provided by the European Union, namely from 2001 onwards when Portugal joined the union, was enough to stimulate the specific study of fishery in a long-run perspective, in so many ways that we still need to know more about. Recently, the history of whale fishery and its collateral subjects have been contemplated in the studies ${ }^{59}$ conducted within the scope of the UNESCO Chair on Ocean's cultural heritage, held at the Universidade Nova de Lisboa, plus the recent projects developed crossing history, biology and marine environment experts. ${ }^{60}$ Another bet has been the investment knowing more about whale fishery and its effects within cross-cultural initiatives and knowledge exchange between countries ${ }^{61}$ and/or institutions and groups, both

56. Rodrigues, Ana Maria S. A. “Projectos de investigação em História Medieval financiados pela FCT nos últimos 10 anos". Medievalista, 9 (2011): 1-27.

57. Project "SAL(H)INAS. História do Sal: natureza e meio ambiente (séculos XV a XIX)". POCI/ HAR/56381/2004 and PPCDT/HAR/56381/2004, coordinated by Inês Amorim. This research started from the I International Seminar on the Portugese Salt, held in Aveiro, in 2004. Based on a comparative perspective, the research group was able to engage different aspects of the salt production, circulation and consumption, which resulted in the II International seminar on the Portuguese Salt, held in Porto in 2006, based on the team's work objectives, results and developments, and a collective studies' publication. About the first international seminar, see Amorim, Inês, coord. I Seminário Internacional sobre o sal português. Porto: Universidade do Porto, 2005. About the second seminar, see Amorim, Inês, coord. A articulação do sal...

58. See Freire, Dulce; Ferreira, Nuno Estevão; Rodrigues, Ana Margarida. Corporativismo e Estado Novo: contributos para um roteiro de arquivos das instituições corporativas (1933-1974). Lisbon: Instituto de Ciências Sociais, 2014.

59. See Brito, Cristina. "Medieval and Early Modern Whaling in Portugal". Anthrozoos, 24/3 (2011): 287 300; Brito, Cristina; Carvalho, Inês, eds. Cetáceos de Portugal: Passado, Presente e Futuro. Lisbon: Escola de Mar-Paleta natura, 2012; Brito, Cristina; Jordão, Vera. “A Baleação medieval e no início da era moderna en Portugal: que nos din as fontes históricas?". Eubalaena, nº 14 (2014): 28-40.

60. Currently, two projects that entangles whale fishery are in progress, both held at the Centre for Overseas History, in Lisbon: "Marine animals and maritime communities in the early modern Atlantic", with Cristina Brito as Principal Researcher, using Centre's own funding, and project "CONCHA: The construction of early modern global Cities and oceanic networks in the Atlantic: An approach via Ocean's Cultural Heritage" (H2020-MSCA-RISE-2017 CONCHA Project nº 777998), with João Paulo Oliveira e Costa as Principal Researcher.

61. See Walker, Timothy. "Acquisition and Circulation of Medical Knowledge within the Early Modern Portuguese Colonial Empire", Science in the Spanish and Portuguese Empires, 1500-1800, Daniela Bleichmar, Paula de Vos, Kristin Huffine, Kevin Sheehan, eds. Stanford: Stanford University Press, 2009: 247-270; Vieira, Nina. “A comparative approach to historical whaling techniques: transfer of knowledge in the 17th century from the Biscay to Brazil", Cross-Cultural Exchange and the Circulation of Knowledge in the First 
in specific chronologies or in the long-run perspective. However, whaling is only one of the species that Portugal are historically attached to. Similar research projects on the history of both Portuguese Cod and Sardine Fishery are much needed, for instance, from all perspectives, despite all the effort previously done.

\section{Final Remarks}

Yet, much of the "generic" assumptions of early twentieth-century scholars remain in vogue about fishery, due to the lack of more profound studies connected to global history contexts, despite the fact that their findings have been strongly challenged by recent studies ${ }^{62}$ in many ways, such as the addition of other species fished in Portugal's coast and the respective techniques to catch them. Furthermore, the connection between naval equipment, levels of fishing productivity according to use of new hardware and transport, as well as the geographical changes in the territory, the men's influence in that territory by fishery activities and his impact on fishing itself, the habits regarding fish consumption and meal preparations ${ }^{63}$ are some examples of how those topics can still be explored by further studies.

It is clear that much has been done so far in terms of fishing and its economic impacts on the Portuguese society and institutions. Nevertheless, the financial context which Portugal would experience during this period does not shine a light on any type of investment on the main group of economic activities that underpins the State's revenues and its productive tissue. Joaquim Romero Magalhães highlighted that for Algarve, during a transition towards to the Early Modern times, in seventeenth and eighteenth centuries, mentioning that the region's fate

O Algarve de Seiscentos e Setecentos fica nas mãos de uma pequena nobreza que não dispõe de capitais para iniciativas que não sabe criar. Não há construção naval, não há indústria. [...] Podem vir as crises comerciais que não se dá uma reaç̧ão industrializadora. Há uma resignação à mediocridade que abre as portas aos mercadores estrangeiros. [...]

Uma estrutura de sobrevivência, de pequena produção, um horizonte de "vida material" restrito mal é irrigada pela economia capitalista. Que existe, que funciona noutro nível, o do mercado internacional a que os naturais não têm acesso directo mas de que dependem.

A ruralização também resulta e provoca, por sua vez, a radicação e isolamento mútuo destes dois planos distintos, o da produção e o da circulação. ${ }^{64}$

Global Age, Amélia Polónia, Fabiano Bracht, Gisele C. Conceição, Monique Palma, eds. Porto: Centro de Investigação Transdisciplinar Cultura, Espaço e Memória-Afrontamento, 2018: 125-143.

62. Pereira, Olegário Nelson Azevedo. Em torno da pesca...: 112-113.

63. Gomes, Sandra Rute Fonseca. Territórios Medievais do Pescado...: 96-97.

64. "would be on the hands of a small nobility that does not dispose on capital for initiatives that they do not know how to foster. There's no naval construction, there's no industry. [...] Commercial crisis can come that there will not be an industrialization reaction. There is a resignation to mediocrity that opens the door to foreign merchants. [...] / A structure of survival, of small production, a horizon of restricted 
The financial impact of Oceanic expansion was essential to bring new sources of income, strongly underpinned by overseas' revenues and monopoly rights, although it put on hold any attempt of building an adequate fiscal and financial system, ${ }^{65}$ fostering a redistributive policy of this wealth among the nobility. On top of that, many sectors of the Portuguese economy which could use some of that capital for investment and development were not contemplated. Furthermore, the economic impact of the Iberian Union (1580-1640), fundamentally caused by the military effort imposed to Portugal and Brazil will result in a tremendous fiscal burden on the people ${ }^{66}$ However, the fishing area seems to have endured, ${ }^{67}$ contradicting the so-called decadence of fishing activities affirmed by Lacerda Lobo. ${ }^{68}$ We still don't know many details of how that transition went on in terms of how it affected all the aspects concerning fishery.

João Brandão de Buarcos, a nobleman and one of King Manuel I's many esquires, briefly described in his praise for the city of Lisbon written by mid-sixteenth century many relevant features of fishing markets at the most important city of the realm. He illustrated one of the many employees involved in the fishery business chain, the cesteiro $^{69}$ (basket man), which was responsible for washing, counting and transport to the local markets and to the peixeiras (saleswomen). Furthermore, he highlights the presence of foreign ships dealing with locals, bringing fresh and salted fish from abroad, specially sardines, paying a 10\% fee on their imports. He dares to affirm that

Também vem no mês de Abril-Maio-Junho muito pescado das armações dos atuns de Sesimbra e Algarve, que não pagam nenhum direito, o que vale grande soma de dinheiro. Pela mesma maneira vêm muitos navios de fora, que será 25/30 cada ano, que valem muito dinheiro, porque cada navio destes vale a seu dono trezentos/quatrocentos mil reais. ${ }^{70}$

\footnotetext{
"material life" is hardly irrigated by the capitalist economy. That exists, which works on another level, that of the international market to which the natives do not have direct access but on which they depend. / Ruralization also results and provokes, on its turn, radicalization and mutual isolation of both those distinctive spheres, that of production and of circulation." Magalhães, Joaquim Romero. O Algarve Económico...: 395.

65. Dominguez, Rodrigo da Costa. O Financiamento da Coroa Portuguesa...: 221-230.

66. Godinho, Vitorino Magalhães. Prix et monnaies au Portugal, 1750-1850. Paris: Librairie Armand Colin, 1955: 381-395; Magalhães, Joaquim Romero. O Algarve Económico...: 404.

67. Magalhães, Joaquim Romero. O Algarve Económico...: 407.

68. Lobo, Constantino Lacerda. "Memória sobre a decadência da pescaria de Monte Gordo", Memórias Económicas da Academia Real das Ciências, 1789-1815, dir. José Luís Cardoso. Lisbon: Banco de Portugal, 1991: III, 251-254.

69. Caessa, Ana; Matos, Francisco. "O Arquivo Histórico da Câmara Municipal de Lisbon: percurso e estrutura". Cadernos do Arquivo Municipal, 3 (1999): 126.

70. "also comes in the month of April-May-June much fish from the ship rigging of tuna fishing of Sesimbra and Algarve, which do not pay any rights, which is worth large sums of money. In the same way, many ships come from outside, which will be $25 / 30$ each year, which are worth a lot of money, because each ship of these goes to its owner three hundred to four hundred thousand reais." Brandão de Buarcos, João. Grandeza e Abastança de Lisbon em 1552, ed. José da Felicidade Alves. Lisbon: Livros Horizonte, 1990.
} 
Father Nicolau de Oliveira, a clergyman who also wrote his own praise to Lisbon a hundred years after, also emphasized the enormous fertility of the Tagus River $^{71}$ and the huge amount of unique and different species, and how those fish could be used for the feeding of ill people. Furthermore, the large number of boats involved in that activity, the extension of fishing season and the catch of several different species of crustaceans (lobsters, crayfish, shrimp, etc) and water snakes, as the lamprey, and how much those were exported to many regions of Castile. Curiously, his manuscript does not mention anything about the cod fishery, despite the pioneer role played by the Portuguese in the 1500s. The control of fishery -at least to what is concerned about cod fishing and its shipping - was ephemeral, passing into Britain's hands, with larger economic, naval and military capacities. ${ }^{72}$ Still, many aspects of their descriptions are not properly known. Are those reports accurate? Were those men also involved into the tax collection process? What about the tax-farming on the fishery taxes? Are they involved in that as well? What about the social habits regarding fish consumption, i.e., a "Portuguese fish social history"? Many questions still remain to be answered by future studies, in a wide range of many options, not only related to economic and social approaches.

71. Oliveira, Frei Nicolau de. Livro das Grandezas de Lisbon. Lisbon: Impressão Régia, 1804: 41-42.

72. For this control shifting in cod industry, see Varela, Consuelo. "A pesca do Bacalhau entre os séculos XV e XVIII", A Pesca do Bacalhau. História e Memória, Álvaro Garrido, coord. Lisbon: Editorial Notícias, 2001: 31-50. See also Innis, Harold. The Cod Fisheries: the History of an International Economy. Toronto: University of Toronto Press, 1954; Starkey, David J.; Reid, Chris; Ashcroft, Neil, eds. England's Sea Fisheries: The Commercial Sea Fisheries of England and Wales since 1300. London: Chatham, 2000. 